\title{
Does the Financial Performance Matter in Accessing to Finance for Libya's SMEs?
}

\author{
Tarek Zarook ${ }^{1}$, Mohammad Mafizur Rahman ${ }^{1} \&$ Rasheda Khanam ${ }^{1}$ \\ ${ }^{1}$ School of Accounting, Economics and Finance, Faculty of Business and Law, University of Southern \\ Queensland, Australia \\ Correspondence: Tarek Zarook, School of Accounting, Economics and Finance, Faculty of Business and Law, \\ University of Southern Queensland, Australia. E-mail: zarroug70@yahoo.com or Tarek.Zarook@usq.edu.au
}

Received: March 26, 2013

Accepted: May 2, $2013 \quad$ Online Published: May 21, 2013

doi:10.5539/ijef.v5n6p11

URL: http://dx.doi.org/10.5539/ijef.v5n6p11

\begin{abstract}
This study investigates the impact of financial performance of small and medium-sized enterprises (SMEs) on access to finance in Libya. The study is based on the primary data of 557 survey questionnaires on SMEs in various sectors of different regions of Libya. The data analysis contains the computation of descriptive statistics, correlation statistics and multivariate regression analysis. Our results confirm that financial performance expressed by liability to assets ratios, profit, return of assets have no significant effects on access to finance in Libya.
\end{abstract}

Keywords: financial performance, small and medium enterprises, access to finance, Libya

\section{Introduction}

Nowadays the small and medium-sized enterprises (SMEs) play a vital role throughout the world. Badulescu (2010) notes explained that SMEs are emerging as the economic engines of many economies worldwide. Abor and Quartey (2010) argued that SMEs as being of immense socio-economic importance to any country. In addition, SMEs are a source of employment for many people across countries. The purpose of this study is to examine the financial performances of SMEs on access to finance in a developing country, Libya. The SMEs have a fundamental role in stimulating the key macroeconomic indicators. Such macroeconomic indicators consist of GDP, exports and rate of employment. Therefore, SMEs are very important to Libyan economy because of the fact that the economy of Libya suffers from lack of economic diversification in her activities.

The performance of small and (SMEs), in comparison with large enterprises (LEs), reveals great differences in the growth determinants and the extent to which these facets yield greater performance from internal and external business perspectives. An examination into the growth phases of SMEs across the world has indicated that small and medium firms face growth challenges because of traditional knowledge that remains within the purview of many it is also revealed that there were positive correlations among productiveness and entrepreneurial orientation (EO) with business performance (Fairoz et al. 2010). The nature of and the profitability of firms has been investigated with sorts of strategies aimed at establishing internal and external efficiencies with regard to expanding the capital structure or improving the financial health of SMEs (Caloghirou et al. 2004; Deloof 2003).

According to Pandula (2011a) financial characteristics affect a firm's ability to get financing. He categorizes the financial characteristics into financial statements, firm performance and tangibility. Pandula explains that greater sales as well as profits increase a firm's accessibility to credit. His argument is consistent with The European Commission study conducted in 2003 which found that poor business performance was one of the major reasons as to why small enterprises did not receive credit. Pandula contends that a firm's financial performance is a key determinant of access to financing as it indicates the firm's ability to refund the loan (Pandula 2011a). Also, Pandula explains that profits return on asset and turnover of sales are some of the factors that financial institutions assess before they give a business loan to any enterprise.

A review of prior studies imply that SMEs with greater profits, increasing sales turnover ratios (good financial performance) face less credit constraints while those with poor financial performance have been found to have very limited access to business credit especially from banks (Pandula 2011a). Most studies have not looked at all 
the main these factors that constitute financial performance. Therefore, the main objective of this study is to identify the effects of financial performance measured by liability to assets ratio, profits and return of assets on access to financing for SMEs in Libya. The study will examine the extent to which financial institutions use the SMEs performance with regard to these parameters to provide them with business credit. Libya has been chosen in this just because SMEs in this country suffer from access to finance.

This study is organized as follows. Section 2 provides literature review. Section 3 explains conceptual model and development of hypothesis. Section 4 discuses research methodology which points out the description of variables, sample, validity, reliability and collected data. Section 5 provides details of data analysis and discusses the results. The final section concludes the papers.

\section{Literature Review}

\subsection{Liability to Assets Ratio for SMEs}

The growth of SMEs has stimulated the need to understand the relationship between liability to asset ratio and the overall profitability of small firms (Drever et al. 2007). This has been necessitated by the fact that as SMEs tend to raise their growth, they grow their asset base with a view of maximizing their returns on investment (Nguyen et al. 2007). the Study by (ALShubiri 2011) in the theory of asymmetric information or pecking order suggest that SMEs prefer internal financing to external debt equity, thus SMEs with higher profitability will tend to use their high-retained earnings as compared to debt equity.

This study is consistent with a study conducted by Abor, J. and Biekpe (2007) which found significant negative relationship between profitability of SMEs and long-term debt measured by the income before tax (IBT) to total assets. According to López-Gracia and Sogorb-Mira (2008), SMEs tend to meet their financing needs in the following pecking order: firstly, they utilize their available net profits; secondly, short-term financing; thirdly, long-term financing; and the least preferred option remains the attraction of new equity investors, which represents the maximum intrusion.

In essence, the pecking order theory postulates that there exists a negative or inverse correlation between profitability and leverage of SMEs, because the more profitable a firm gets, the less it requires borrowing or external equity (López-Gracia et al. 2008). The study finds a lot of backing from numerous sources that have, in their research, established the higher affinity for short-term debt by small firms with less focus on long-term debt equity. Although the facts show that this trend is a natural element faced by most SMEs, studies have shown that the shift toward short-term equity is due to shareholder-lender conflicts.

In relation to liquidity, Manos, Murinde and Green (2012) indicate that the cash ratio (liquidity ratio) exhibits a firm's ability to settle its short-term liabilities in real time. Therefore, their study concluded that it is highly likely that highly liquefied firms tend to embrace short-term borrowing compared to SMEs with less efficient liquidity synergies. Numerous studies contend that leverage and liquidity will display a negative relationship as SMEs generate their internal efficiencies to finance their short-term obligations while avoiding interest costs.

However, it should be noted that, as firms grow their asset portfolios, they generate appetite from the lenders, who emphasize the "collaterality" of the financing process. There is a significant relationship between asset capacity of firms and long-term debts. In long-term financing, Deloof (2003) asserted that the capital structure of firms plays a significant role in establishing lending and borrowing relationships between SME owners and financiers. As such, there is a strong positive relationship between the asset structures of SMEs (as measured by the proportion of fixed assets to total assets) and long-term debt.

\subsection{Profits for SMEs}

As SMEs strive toward growth, the need for a profitable entity remains a key focus for all enterprises across all industries. Studies have indicated that SMEs' problems occur during the moment of growth and development during which the expenditures on asset acquisition and research \& development (R\&D) increase considerably (Deloof 2003). This scenario creates a higher need for external funding, which particularly affects profitability because interest paid reduces the net profitability and the surpluses available for distribution as shareholder dividends (sánchez et al. 2011).

Although profitability increases with the growth of SMEs, the increasing need for funds to finance their operations impedes their efforts to profit due to the accumulation and consideration of losses before profits (Raheman et al. 2007). How can SMEs attempt to grow and maximize their profitability without sacrificing their return on investments? Losses occur when the managerial elements have lost control in of expenditures (Bamiatzi et al. 2009). Therefore, cost management becomes a critical element that can spur profitability for SMEs. When expenditures do increase, studies suggest that SMEs seeking to succeed must stimulate their profit 
inlets by focusing on the short-term profit alternatives available to them. Many SMEs tend to work hard with a view to embrace long-term profitability, but the analysis of SMEs experiencing strategic growth challenges proposes the use of short and rigorous strategies to overcome the constraints of creating profit ventures (Deloof 2003).

\subsection{Return on Assets for SMEs}

The concept of return on assets (ROA) and its influence on the performance of businesses has emerged strongly to capture the attention of many stakeholders. Corporate finance deals regarding capital structure decisions, working capital, and capital management decisions remain instrumental in establishing strong and plausible firms. Studies show that, although the elements of working capital are crucial in establishing the extent to which businesses achieve their profitability, it continues to receive less attention in the mainstream business world (Major 2008).

In examining the essence of return on assets, one should endeavour to consider the specific components that converge to realize the overall working capital structure of a business. The study by (ALShubiri 2011) has attempted to suggest that over-reliance on current liabilities while holding low or inadequate current assets may cause a firm to incur shortages. To establish a plausible working capital structure, an organization has the responsibility of implementing succinct measures aimed at building a strong foundation for a formidable working capital (Rivaud-Danset et al. 2001). According to numerous studies, many financial institutions have over-emphasized the need for a sound ROA for SMEs in order to generate impetus for lending (Mac An Bhaird et al. 2010).An analysis into the nature of SME financing across the world suggests that financing for SMEs by banks and other financial institutions have relied solely on the extent to which SMEs concretize their management in realizing strong financial returns on their overall investments. Perhaps, it may be observed that since asset values remain critical items on loan obligations, banks have developed strategies to discriminate against SMEs that seem to exhibit low or poor ROA. The issue of ROA is a double-ended blade that cuts on all sides of the investment group-the banks and the SMEs themselves.

Firms that concentrate their performance in building a strong current asset portfolio run the risk of negative profitability whereas firms with low current assets tend to have difficulty in maintaining smooth operations due to their inability to sustain their daily liquid demands (Shah 2010). The need to create and sustain an efficient working capital remains an arguable step toward ensuring the profitability of SMEs. This reason has made banks revolve around the idea of ROA and the extent to which SMEs turn them around to generate synergies in their business operations (Rivaud-Danset et al. 2001) .One of the questions that may spur the debate could be, "has the reliance on ROA blurred the extent to which financial institutions can create other synergies for better performance or does the return on assets exclusively explain why SMEs have the energy to demonstrate ability to repay their long-term debt obligations"? According to Nazir and Afza (2009), although the managerial facets such as marketing, operational efficiencies, and manufacturing have spurred the growth of traditional SMEs, working capital and its consequential returns have had enormous effects on small and medium-sized businesses and their survival. In his study, ALShubiri (2011) proposed that the act of better management of working capital by SMEs remains significant in turning these enterprises into financially healthy business in all respects (Wang et al. 2010).

The ability of a firm to efficiently translate its asset base into a tangible benefit of a financial nature speaks volumes in stimulating investors and financiers to structure their investment and lending decisions (Aquino 2010).In a study on how SMEs responded to the dynamics of the economic environment within which they operated shows that the overall generation of SMEs was a function of, current ratio, current assets to total assets ratio, and the inventory to total assets ratio. Additionally, these facets unanimously worked as a measure of properly functioning working capital. Converse to the expectations of the study, it was found that there existed a relatively small correlation between the dynamics of economic environment and changes in the constituents of working capital (Leitner et al. 2010).

\section{Conceptual Model and Hypotheses $(\mathrm{H})$}

Pandula (2011b) explains that firm performance has a great influence on access to credit. Research implies that greater profits as well as sales are associated with greater access to financing (Pandula 2011b). Firms with increasing sales and sales turnover have less constraint on credit, while poor performing firms have been found to have limited access to financing, particularly by banks. Access to finance is required to fill up financial gap of the firms. The following conceptual model indicates the presence of financial gap. The financial gap is still a source of concern and difficulty faced by SMEs.This study tests the relationship between financial performances and access to finance for SMEs by four variables. Therefore, the financial performance measured by liability to 
assets ratio, profit and returns of asset may have impact on access to finance. Based on the conceptual framework and literature described above, a hypothesis is developed as follows:

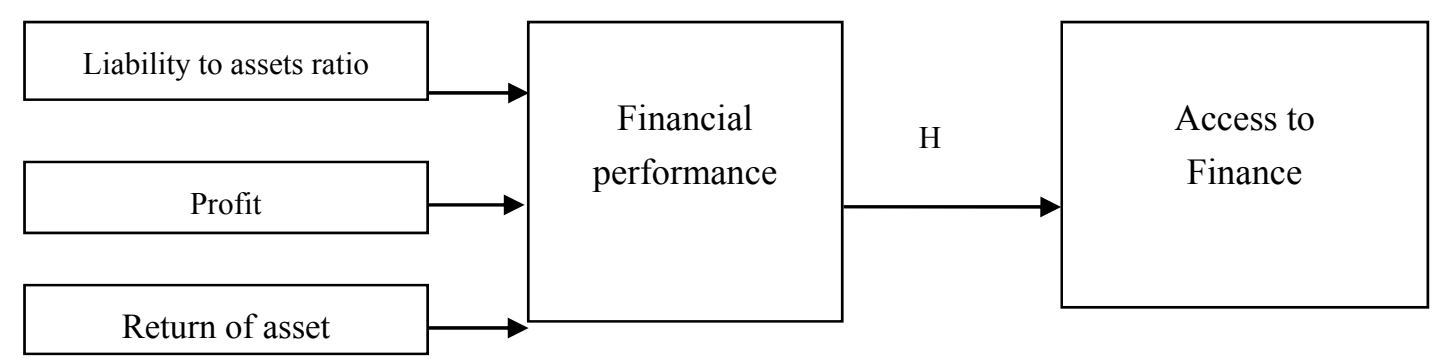

Figure 1. Conceptual model

H: A higher level of financial performance has a positive impact on SMEs'access to financing and vice versa.

The following model was employed to examine the validity of this hypothesis:

$$
A T F=\alpha+\beta_{1} L A R+\beta_{2} \quad P R O+\beta_{3} R O A+\varepsilon
$$

Where $\mathrm{ATF}=$ access to finance, $\mathrm{LAR}=$ liability to assets ratio, $\mathrm{PRO}=$ Profit

LAR, PRO, ROA were employed to measure financial performance and their impact on ATF.

\section{Research Methodology}

\subsection{Description of Variables}

\subsubsection{Access to Finance}

Access to finance for small and medium enterprises in Libya can be described as the proximity of such SMEs to sources of funding such as loans from banks, funding from venture capitalists, equity capital, other forms of debt financing, equity finance, debt finance, banking finance, family finance, Islamic finance, Musharaka financing, grants and guarantees among others (Beck et al. 2005).

\subsubsection{Financial Performance}

Financial performance of SMEs in Libya can be described as how well the SMEs utilize the resources availed to them to generate profits, revenues and fuel their growth in terms of assets and value. In addition, SMEs in Libya perform much better than the large corporations due to their proximity to local resources and capabilities, as well as the low operational costs associated with such firms (Beck et al. 2006). Such performance is vital in the quest by SMEs to source funding. The performance of the SMEs can be measured in terms of debt management which is the level of debt used to finance the firm's total assets measured using the liability to asset ratio profitability which is the ability of the firm's revenue to exceed their expenditure and it will be measured by the return on assets and the amount of profits generated by the SMEs; and, finally, the SMEs growth rate which shall be measured by the amount of revenues generated by the SMEs per year (Beck et al. 2008).

\subsubsection{Liability to Assets Ratio}

Liability to assets ratio for SMEs in Libya is used to determine the level of debt that is used to finance firms' total assets and it is a measure of the SMEs' proportion of debt in their capital structure. This ratio is used to determine how well the SMEs utilize leverage to finance their operations which, in effect, determines their credit worthiness a factor that is highly useful in the process of accessing finance, especially debt finance (Beck et al. 2008)

\subsubsection{Profit}

Profit generated by SMEs in Libya can be described as the excess of the SMEs' revenues over their expenditure. Presence of profits indicates that the SMEs are sound and profitable and as such they are attractive to providers of capital because they can have confidence that they will obtain a return on their investment (Vos et al. 2007). This indicates that the SMEs' access to finance will be enhanced if they are profitable or, in contrast, it will be difficult for them access funds if they are unprofitable. The profits can be measured in various ways and includes the gross profit, operating profit and net profit. Gross profit refers to the difference between the revenues generated by the SMEs and the cost of sales. Operating profit is calculated by subtracting operating costs from the gross profit and net profit is calculated by subtracting operating costs, as well as all other cost and taxes from 
the gross profit (Froeb et al. 2009; Vos et al. 2007).

\subsubsection{Return of Asset}

The return on assets (ROA) ratio is a business profitability ratio that evaluates the efficiency with which profits are being derived from the assets of a business. Basically, the financial ratios measure the quantity of profits earned from each shilling worth of the business's assets. It evaluates the capacity of the business to create profits prior to leverage through using business assets. The ROA basically compares the average total of assets with net income. The return on assets ratio avoids using leverage arising from owner's equity and from other debt obligations.

\subsection{Sample}

In selecting participants, a random sampling method is used. The method is involved choosing sample units such that each population unit has an equal and independent chance of being selected and included in the sample. The target population is the 180,000 SMEs listed by the Libya Ministry of Economy and Trade. The sample in this research includes Libyan SMEs in various sectors such as, service sector and manufacturing sector, Selection of SMEs were based on size of employment ranging from 10-200 (see table 1). The sample comprises 600 SMEs many researchers have established that this is optimal size for quantitative surveys (Perry 1995).

Table 1. Classification of SMEs in Libya

\begin{tabular}{ll}
\hline Size of employment & Classification project \\
\hline $1-9$ employees / works & Micro small business \\
$10-49$ employees /works & Small business \\
$50-200$ employees /works & Medium business \\
$201-250$ employees /works & Large business \\
\hline
\end{tabular}

Source: Prepared by the researchers.

\subsection{Data}

The data for this study were collected from the managers or owners of small and medium-sized firms in Libya via questionnaire. The researcher chose to focus on the country's larger industrial cities such as Tripoli, Benghazi, Misurata, Sabha, Koms, Zawya and Zwara because the majority of small and medium enterprises are located in these areas. The survey questionnaires were distributed through personal visits and by mail. The researcher provided instructions on how to complete the questionnaires were and discussed who in each business should respond to the questionnaires. Altogether, 600 questionnaires were distributed to SMEs in Libyan industries such as services and training, health services, industrial design, agricultural products, and tourism. A total of 557 responses were collected from SMEs in various regions in Libya.

\section{Data Analysis and Discussion}

\subsection{Validity and Reliability Evaluation of Financial Performance of the SMEs}

The validity and reliability are very significant to establish of the business research. The validity and reliability of the research findings should be ensured through the adoption of randomised procedures while selecting participants in a number of SMEs (Carmines et al. 1979). Subjectivity and favouritism should be avoided at all costs. The results should, thus, be a true representation of the targeted population. Validity and reliability should also be ensured by conducting tests and retests to confirm that similar results are obtained.

Table 2 shows the reliability evaluation of financial performance for the SMEs. Cronbach's alpha tests inter-items consistency and the variables of financial performance for SMEs. Therefore, the Cronbach's alpha reflects how well items are positively associated with elements in combination with each other in the questionnaire relate to financial performance. Reliability statistics of Cronbach's alpha is 0.7 and is interpreted as acceptable according to (Calaguas et al. 2011). Moreover, the analysis items (Table 2) illustrate that the Cronbach's alpha is interpreted as 0.7 and deemed acceptable for liability to assets (LAR) and profit (PRO). The Cronbach's alpha for return of asset (ROA) is 0.8 The study by Islam et al ( 2011) supports reliability statistics related to this analysis. 
Table 2. The validity results of each item of the questionnaire

\begin{tabular}{lll}
\hline Number of item & Item-total correlation & Cronbach's Alpha (If an item deleted) \\
\hline LAR & 0.74 & 0.792 \\
PRO & 0.738 & 0.789 \\
ROA & 0.685 & 0.808 \\
\hline
\end{tabular}

Note: Liability to assets $=$ LAR, Profit $=$ PRO, Return of asset $=$ ROA.

\subsection{Financial Performance and Access to Finance by SMEs}

In this analysis, the research explores some of the critical elements that continue to pose great challenges in developing and growing SMEs. Quite often, these elements, which usually appear to be constraints, begin to relate inversely during a small firm's course of growth. The research considers liability to asset ratio of SMEs, along with their return on assets, profitability. The analysis of the literature focused on the determination of the existence and the extent of the causal relationship between SME growth patterns and the listed factors as the key players in the establishment of sustainable development of small and medium-sized enterprises. The following section details analysis of the relationship between financial performance and access to finance by using descriptive statistics and correlation statistics for independent and dependent variables.

\subsection{Descriptive Statistics of Financial Performance and Access to Finance}

Table 3 illustrates the descriptive statistics for financial performance and access to finance. Table 3 shows that the mean of variables ranges from a maximum of (38.75) to a minimum of (1). It also shows most of the variables have similar maximums and the minimum ranges between 1 and 2 .

Table 3. Descriptive statistics of financial performance and access to finance

\begin{tabular}{llllll}
\hline Descriptive Statistics & \multicolumn{7}{l}{} \\
\hline & $\mathrm{N}$ & Minimum & Maximum & Mean & Std. Deviation \\
\hline ATF & 557 & 15 & 38.75 & 28.2724 & 4.23 \\
LAR & 557 & 1 & 5 & 3.026 & 0.717 \\
PRO & 557 & 2 & 5 & 3.481 & 0.627 \\
ROA & 557 & 1 & 5 & 3.373 & 0.694 \\
Valid N (listwise) & 557 & & & & \\
\hline
\end{tabular}

Notes: Access to finance $=$ ATF, Liability to assets $=$ LAR, Profit $=$ PRO, Return of asset $=$ ROA.

The dependent variable (access to finance) records the maximum mean (28.2724), whereas the highest mean of the independent variables is profit of SMEs (PRO) (3.481). In contrast, the lowest mean in this table is liability to assets (LAR) at (3.026). In contrast, the PRO of SMEs is observed to have the lowest volatility with standard deviation (0.627).

\subsection{Correlation Coefficients of Financial Performance and Access to Finance}

The descriptive statistics and correlation coefficients reiterate the measurement of the strength of the liner relationship between variables of this model. This means the range of correlation coefficient analysis is $(+1)$ to $(-1)$. The correlation coefficients of the financial performance (ATF, LAR, PRO, and ROA) and access to finance (ATF) have been organised and reported in Table 4.

Table 4 shows that there is weak correlation between financial performance (LAR, PRO, ROA and REV) and ATF. Therefore, this will reflect on the ability of the model to test these elements. In addition, most of the independent variables are positively correlated with each other. More specifically, profit (PRO) has higher correlation with liability to assets (LAR) with a value $(0.362$, P-value $<0.01)$. Moreover, return of asset (ROA) has a higher positive correlation with LAR $(0.221$, P-value $<0.01)$ and lower negative correlation with POR with value $(-0.950, \mathrm{P}$-value $<0.05)$. REV represents the final factor in this analysis. 
Table 4. Correlation coefficients of financial performance and access to finance

\begin{tabular}{|c|c|c|c|c|c|}
\hline \multicolumn{6}{|c|}{ Correlation statistics of financial performance and access to finance } \\
\hline & & ATF & LAR & PRO & ROA \\
\hline \multirow[t]{3}{*}{ ATF } & Pearson Correlation & 1 & & & \\
\hline & Sig. (2-tailed) & & & & \\
\hline & $\mathrm{N}$ & 557 & & & \\
\hline \multirow[t]{3}{*}{ LAR } & Pearson Correlation & -0.016 & 1 & & \\
\hline & Sig. (2-tailed) & 0.698 & & & \\
\hline & $\mathrm{N}$ & 557 & 557 & & \\
\hline \multirow[t]{3}{*}{ PRO } & Pearson Correlation & -0.005 & $0.362 * *$ & 1 & \\
\hline & Sig. (2-tailed) & 0.905 & 0.000 & & \\
\hline & $\mathrm{N}$ & 557 & 557 & 557 & \\
\hline \multirow[t]{3}{*}{ ROA } & Pearson Correlation & 0.014 & $0.221 * *$ & $-0.95 *$ & 1 \\
\hline & Sig. (2-tailed) & 0.74 & 0.000 & 0.025 & \\
\hline & $\mathrm{N}$ & 557 & 557 & 557 & 557 \\
\hline
\end{tabular}

Notes: **Correlation is significant at the 0.01 level (2-tailed); ${ }^{*}$ Correlation is significant at the 0.05 level (1-tailed). Access to finance $=$ ATF, Liability to assets $=$ LAR, Profit $=$ PRO, Return of asset $=$ ROA

\subsection{The Result}

To verify this hypothesis and to check if the independent variables (financial performance) have a positive effect on financing of SMEs, this study used ANOVA to clarify and examine the relationship between dependent (access to finance) and independent (financial performance) variables as shown in Table 5.

Table 5. ANOVA analysis of the equation related to hypothesis

\begin{tabular}{llllrrrrr}
\hline ANOVA $^{\mathrm{a}}$ & \multicolumn{10}{c}{} & & & & \\
\hline Model & Sum of Squares & df & Mean Square & $\mathrm{F}$ & $\mathrm{R}^{2}$ & Adjust $\mathrm{R}^{2}$ & Durbin-W & Sig \\
Regression & 16.705 & 4 & 4.176 & 0.231 & 0.572 & 0.498 & 1.701 & 0.921 \\
Residual & 9960.765 & 552 & 18.045 & & & & & \\
Total & 9977.47 & 556 & & & & & & \\
\hline
\end{tabular}

a. Dependent Variable: ATF. b. Predictors: (Constant), LAR , PRO, ROA. ATF= Access to finance, LAR $=$ Liability to assets PRO= Profit, $\mathrm{ROA}=$ Return of asset.

From Table 5 it can be seen that there is no relationship between access to finance and financial performance. This implies that, the hypothesis is not supported at least in the situation of Libya because this factor is statistically significantly very weak $(0.921, \mathrm{P}$-value $>0.05)$. To verify the weak relationship between access to finance and financial performance, this study analyses the variables of financial performance (liability to assets (LAR), profit (PRO) return of asset (ROA) and access to finance (see Table 6).

Table 6. Coefficients of the equation related to hypothesis

\begin{tabular}{llllll}
\hline Coefficients & \multicolumn{2}{l}{} \\
\hline Model & \multicolumn{2}{l}{ Unstandardized Coefficients } & Standardized Coefficients & $\mathrm{t}$ & Sig \\
& $\mathrm{B}$ & Std. Error & Beta & & \\
Constant & 28.497 & 1.486 & & 19.183 & 0.000 \\
LAR & -0.139 & 0.28 & -0.024 & -0.495 & 0.620 \\
PRO & 0.108 & 0.329 & 0.016 & 0.328 & 0.743 \\
ROA & 0.119 & 0.271 & 0.02 & 0.44 & 0.660 \\
\hline a. Dependent Variable: ATF & & & &
\end{tabular}

Notes: a. Dependent Variable: ATF. Access to finance $=$ ATF, Liability to assets= LAR, Profit= PRO, Return of asset ROA.

Table 5 and 6 provides a description of the influence of financial performance (liability to assets, profit and return of asset) on access to finance. The results indicate that there is no significant relationship between access to finance and financial performance. In addition, the $\mathrm{R}^{2}$ is 0.572 and this explains the changes that happen to the dependent variable with the average of $8 \%$ of P-value of the regression. This is due to the existence of three independent variables which are liability to assets, profit, and return on asset; while the other $92 \%$ refers to other 
interior factors or simply to coincidence. Therefore, the hypothesis of the study is not supported because the relationship between access to finance and financial performance is insignificant.The findings of this study indicate that there is negative relationship between the liability to assets and access to finance with coefficient $(-0.139)$, but this coefficient is insignificant with the access to finance. In contrast, the profit (PRO) and return of asset (ROA) should have positive correlated with access to finance. This argues has been confirmed in the Table 6 higher PRO and ROA Leads to increase access to finance. The reason behind this finding is that the negative sign of liability to assets indicating that the shareholder of SMEs equity is low in Libya SMEs. On the other hand, the insignificant positive sign of PRO and ROA indicates that the management of SMEs is not being managed well.

\section{Conclusions}

We have attempted to investigate the impact of financial performance for SMEs on access to finance in Libya. We have pointed out the variables from theoretical and conceptual points are considered as the measures of financial performance and explored their impact on access to finance in Libyan SMEs. This research has found no significant influence of financial performance on access to finance in Libyan's SMEs. This is surprising result contrary to the many studies in the existing literature. This may be due to the fact that some other factors such as, socio- demographic and political factors are playing a vital role in accessing to financing of SMEs in Libya. The further research should be directed to explore these issues.

\section{References}

Abor, J., \& Biekpe, N. (2007). Small business reliance on bank financing in Ghana. Emerging Markets Finance and Trade, 43(4), 93-102. http://dx.doi.org/10.2753/REE1540-496X430405

ALShubiri, F. N. (2011). The Effect of Working Capital Practices on Risk Management: Evidence from Jordan. Global Journal of Business Research, 5(1), 39-54, 2011.

Aquino, S. (2010). Accounting indicators for credit risk analysis of firms: a historical perspective. Economia Aziendale Online, 1(2), 145-54.

Bamiatzi, V., \& Hall, G. (2009). Firm versus sector effects on profitability and growth: The importance of size and interaction. International Journal of the Economics of Business, 16(2), 205-20. http://dx.doi.org/10.1080/13571510902917517

Beck, T., \& Demirguc-Kunt, A. (2006). Small and medium-size enterprises: Access to finance as a growth constraint. Journal of Banking \& Finance, 30(11), 2931-43.

Beck, T., Demirgüçkunt, A., \& Maksimovic, V. (2005). Financial and legal constraints to growth: does firm size matter? The Journal of Finance, 60(1), 137-77. http://dx.doi.org/10.1111/j.1540-6261.2005.00727.x

Beck, T., Demirguc-Kunt, A., Laeven, L., \& Levine, R. (2008). Finance, firm size, and growth. Journal of Money, Credit and Banking, 40(7), 1379-405. http://dx.doi.org/10.1111/j.1538-4616.2008.00164.x

Calaguas, G. M., \& Dizon, C. S. (2011). Development and initial validation of the social competency inventory for tertiary level faculty members. International Journal of Human and Social Sciences, 6(3), 171-6.

Caloghirou, Y., Protogerou, A., Spanos, Y., \& Papagiannakis, L. (2004). Industry-Versus Firm-specific Effects on Performance: Contrasting SMEs and Large-sized Firms. European Management Journal, 22(2), 231-43. http://dx.doi.org/10.1016/j.emj.2004.01.017

Carmines, E. G., \& Zeller, R. A. (1979). Reliability and validity assessment. Sage Publications, Inc.

Deloof, M. (2003). Does working capital management affect profitability of Belgian firms? Journal of Business Finance \& Accounting, 30(3-4), 573-88. http://dx.doi.org/10.1111/1468-5957.00008

Drever, M., \& Hutchinson, P. (2007). Industry Differences in the Determinants of the Liquidity of Australian Small and Medium Sized Enterprises. Small Enterprise Research: The Journal of SEAANZ, 15(1), 60. http://dx.doi.org/10.5172/ser.15.1.60

Fairoz, F. M., Hirobumi, T., \& Tanaka, Y. (2010). Entrepreneurial Orientation and Business Performance of Small and Medium Scale Enterprises of Hambantota District Sri Lanka. Asian Social Science, 6(3), 34.

Fama, E. (1980). Agency Problems and the Theory of the Firm. The Journal of Political Economy, 88(2), 288-307. http://dx.doi.org/10.1086/260866

Froeb, L. M., \& McCann, B. T. (2009). Managerial Economics: A Problem Solving Approach. South-Western Pub. 
Islam, A., Aktaruzzaman Khan, M., Obaidullah, A. Z. M., \& Syed Alam, M. (2011). Effect of entrepreneur and firm characteristics on the business success of small and medium enterprises (SMEs) in Bangladesh. International Journal of Business and Management, 6(3), 289.

Jensen, M. (1983). Organization theory and methodology. Accounting Review, 58(2), 319-39.

Jensen, M., \& Meckling, W. (1976). Theory of the firm: Managerial behavior, agency costs and ownership structure. Journal of financial economics, 3(4), 305-60. http://dx.doi.org/10.1016/0304-405X(76)90026-X

Leitner, K. H., \& Güldenberg, S. (2010). Generic strategies and firm performance in SMEs: a longitudinal study of Austrian SMEs. Small Business Economics, 35(2), 169-89. http://dx.doi.org/10.1007/s11187-009-9239-x

López-Gracia, J., \& Sogorb-Mira, F. (2008). Testing trade-off and pecking order theories financing SMEs. Small Business Economics, 31(2), 117-36. http://dx.doi.org/10.1007/s11187-007-9088-4

Mac An Bhaird, C., \& Lucey, B. (2010). Determinants of capital structure in Irish SMEs. Small Business Economics, 35(3), 357-75. http://dx.doi.org/10.1007/s11187-008-9162-6

Major, I. (2008). Technical Efficiency, Allocative Efficiency and Profitability in Hungarian Small and Medium-Sized Enterprises: A Model with Frontier Functions. Europe-Asia Studies, 60(8), 1371-96. http://dx.doi.org/10.1080/09668130802292200

Manos, R., Murinde, V., \& Green, C. J. (2012). Dividend policy and business groups: Evidence from Indian firms. International Review of Economics \& Finance, 21(1), 42-56. http://dx.doi.org/10.1016/j.iref.2011.05.002

McMahon, R., Holmes, S., Hutchinson, P., \& Forsaith, D. (1993). Small enterprise financial management: Theory \& practice. Harcourt Brace San Diego.

Nazir, M. S., \& Afza, T. (2009). Impact of aggressive working capital management policy on firms' profitability. The IUP Journal of Applied Finance, 15.

Nguyen, T. D. K., \& Ramachandran, N. (2007). Capital structure in small and medium-sized enterprises: the case of Vietnam. ASEAN Economic bulletin, 23(2), 192-211. http://dx.doi.org/10.1355/AE23-2D

Pandula, G. (2011a). An empirical investugtion of small and medium enterprises Access to finance: The case of an emerging economy. Proceedings of the ASBBS Annual Conference, Las Vegas, 255-73, Retrieved from http://asbbs.org/files/2011/asbbs2011v1/pdf/p/pandulag.pdf

Pandula, G. (2011b). An Empirical Investigation of Small and Medium Enterprises' Access to Bank Finance: The Case of an Emerging Economy. Proceedings of ASBBS, Annual Conference, 18(1), 18.

Perry, C. (1995). A structured approach to presenting PhD theses: Notes for candidates and their supervisors. ANZ Doctoral Consortium.

Raheman, A., \& Nasr, M. (2007). Working capital management and profitability-case of Pakistani firms. International review of business research papers, 3(1), 279-300.

Rivaud-Danset, D., Dubocage, E., \& Salais, R. (2001). Comparison between the financial structure of SMES and that of large enterprises (LES) using the BACH database. European Economy-Economic Papers.

Sánchez, A. G., Popescu, D., Chivu, I., Ciocârlan-Chitucea, A., \& Popescu, D. O. (2011). How to Improve Small and Medium-Sized Enterprises Profitability by Practicing an Efficient Human Resources Management. Theoretical and Applied Economics, 18(1), 49-64.

Shah, S. (2010). Financing the Current Assets: Approach Followed by Small and Medium Enterprises in Pakistan. Interdisciplinary journal of contemporary research in business, 2(7), 10.

Vos, E., Yeh, A. Y., Carter, S., \& Tagg, S. (2007). The happy story of small business financing. Journal of Banking \& Finance, 31(9), 2648-72. http://dx.doi.org/10.1016/j.jbankfin.2006.09.011

Wang, Y., \& Poutziouris, P. (2010). Leadership styles, management systems and growth: empirical evidence from uk owner-managed smes. Journal of enterprising culture (jec), 18(3), 331-54. http://dx.doi.org/10.1142/S0218495810000604 